\title{
Recovery of Olfactory and Gustatory Dysfunctions in COVID-19 Patients in Iran: A Prospective Cohort Study
}

\section{Mohammad Hosein Taziki Balajelini}

Golestan University of Medical Sciences and Health Services

\section{Mohammad Ali Vakili}

Golestan University of Medical Sciences and Health Services

Abdolhalim Rajabi

Golestan University of Medical Sciences and Health Services

Masoud Mohammadi

Golestan University of Medical Sciences and Health Services

Alijan Tabarraei

Golestan University of Medical Sciences and Health Services

Seyed Mehran Hosseini ( $\nabla$ hosseini@goums.ac.ir)

Neuroscience Research Center Golestan University of Medical Sciences https://orcid.org/0000-00024783-7428

\section{Research article}

Keywords: COVID-19, Pandemic, Gustatory, dysfunctions, Olfactory, Golestan Province

Posted Date: December 23rd, 2020

DOl: https://doi.org/10.21203/rs.3.rs-132300/v1

License: (c) (i) This work is licensed under a Creative Commons Attribution 4.0 International License. Read Full License 


\section{Abstract}

Background: Olfactory and gustatory dysfunctions (OD and GD) manifested unpredictably in COVID-19 patients. Considering the high prevalence of $\mathrm{OD}$ and GD and the importance of the sense of smell and taste in the quality of life, this study aimed to determine the association of some demographic and clinical factors with OD and GD recovery in COVID-19 patients in Iran.

Methods: This prospective cohort study was performed on COVID-19 patients with OD and GD during the first and second peak of pandemic in Golestan province, Iran. We used a local health care registry system for data collection. All cases had positive RT-PCR test for SARS-CoV-19 in nose and nasopharynx swab samples. Variables included age, sex, ethnicity, geographical location, time of onset of symptoms, severity of OD and GD (complete or partial). The follow-up time for recovery from OD and GD was six months. Time to recovery for OD and GD was estimated by Kaplan-Meier considering complete recovery as an endpoint. Differences among groups were evaluated using log-rank test and Cox proportionalhazard models as appropriate in SPSS version 16.

Results: A total of 242 patients completed the study. The mean age of patients was $39.12 \pm 11.89$ years. There were 127 (52\%) females. After six months, 239 (98.8\%) patients had complete OD recovery and $80.9 \%$ and $83.56 \%$ of patients recovered within the first 30 days following the onset of OD or GD, respectively. The mean time of OD recovery was significantly higher (35.07 \pm 4.25 days) in cases infected in the first peak of pandemic than in the second peak $(21.65 \pm 2.05$ days $)(p=0.004)$. This finding also was observed for the recovery time of GD ( $p=0.005)$. The mean recovery time of GD was significantly higher in women than men ( $35.55 \pm 4.33$ vs. $23.20 \pm 2.46$ days) $(p=0.04)$. The age (less than 20 years), second peak of epidemic, and partial dysfunction were identified as significant predictors for recovery.

Conclusions: COVID-19-related OD and GD had high rate of recovery in the first month from onset of symptoms. Age of patients, severity of OD/GD and infecting in second peak of epidemic might be related to the recovery of OD or GD in patients with COVID-19.

\section{Introduction}

Coronaviruses can cause a wide range of disorders from mild acute upper respiratory tract infections to severe life treating diseases including SARS, MERS and COVID 19 (1-3). The coronavirus pandemic is developed by severe acute respiratory syndrome coronavirus 2 or SARS-CoV-2 virus. The clinical manifestations of COVID 19 are diverse and include olfactory and gustatory dysfunctions (OD and GD) (4-7). However, the OD or GD in COVID 19 has unique properties and differs from OD or GD in other viral disease. They are very common and are known as a principal manifestation of disease and in most cases are independent to nasal congestion or rhinitis (8). The incidence of OD has been reported in various studies from a minimum of $0.5-0.65 \%$, to a maximum of $0.86-0.88 \%(9,10)$. The virus has a strong tendency to infect the olfactory system (11). The virus can also enter the brain through the olfactory bulb $(12,13)$. It is strongly recommended that in COVID 19 pandemic all patients with the OD 
should be isolated (14). OD may lead to disruption of daily activities, mood disorders, decreased appetite, and decreased quality of life (15). Since the sense of smell contributes to the sense of taste, patients with hyposmia or anosmia also have difficulty in taste sensation and may have impairments in appetite and enjoyment of food (16). There are still many questions for otolaryngologists and neurologists about the prognosis of OD and GD (17). There are several studies about the short-term outcome of OD and GD in COVID 19 and most of them report good recovery in most cases. However, there are limited reports regarding the long-term outcome of OD recovery and its prognosis; especially in a minority of patients that suffering from OD for more prolong time (17-20). Considering the high prevalence of OD and GD in COVID 19 and the importance of the sense of smell and taste in the quality of life, this study aimed to determine the association of some demographic and clinical factors with OD and GD recovery during the coronavirus pandemic in Golestan province.

\section{Methods}

This clinical-based prospective cohort study was undertaken between March 25th and October 24th, 2020 in Golestan province, in northeastern Iran. The study was approved by the Ethics Committee of Golestan University of Medical Sciences (No. IR.GOUMS.REC.1399.031). Patients received clear oral information. Their oral consent was obtained through telephone interviews.

The patients were identified from a local health registry system. It was a computerized database of electronic health records. All patients diagnosed as having COVID-19 by reverse transcriptase PCR (RTPCR) test for SARS-CoV-2 from nasopharyngeal swabs. Among them, outpatient cases with OD were included in the study. The OD and GD were assessed as a self-report. The exclusion criteria were as follows: patients with a history of cognitive disorders, and patients with OD and/or GD known before the epidemic.

Demographic data including sex, age, and general symptoms were collected from the electronic health records. Information about OD and/or GD of each patient, including the duration of the symptoms and the time to recovery were obtained by telephone interview. Patients were followed by dedicated online surveys from March 25th and October 24th 2020. The grade of OD and GD was defined as "partial" or "compete" to avoid subjective interpretations. All patients were then contacted by telephone up to four times to complete the study. The study follow-up was stopped on October 24, 2020.

A descriptive analysis was performed. Categorical variables were described as frequency rates and percentages, and continuous variables were described using mean, median, and standard deviation (SD). Time to recovery for OD and GD was estimated by Kaplan-Meier curves considering complete recovery as an endpoint. Differences among groups were evaluated using log-rank test and Cox proportional-hazard models as appropriate. Variables analyzed were age, gender, ethnicity, morbidity in two epidemic waves (February to April, and May to July), onset of OD, grade of OD, gastrointestinal dysfunction, and timing of presentation of OD and GD. Multivariable analysis was performed with Cox proportional hazards models including all variables. Statistical Package for the Social Sciences for Windows (SPSS version 26, 0; IBM 
Corp, Armonk, NY, USA) was used to perform the statistical analyses. A level of $p<0.05$ was used to determine statistical significance.

\section{Results}

A total of 242 patients completed the study. The mean age of patients was $39.12 \pm 11.89$ years (range 975). There were 127 (52\%) females and 115 (48\%) males. The following ethnicities composed the cohort: Fars (49.6\%), Turkmen (45\%), and Sistani (5.4\%). 117 cases were from the first wave (February to April) and 125 cases were from the second wave (May to July) of COVID-19 epidemic in Iran. (Table 1). 
Table 1

Characteristics of COVID-19 Patients Presenting with Olfactory/Gustatory Dysfunction

\begin{tabular}{|c|c|}
\hline Variable & Frequency \\
\hline Age, mean (SD), years & $39.12 \pm 11.89$ \\
\hline \multicolumn{2}{|l|}{ Age, $n(\%)$, year } \\
\hline$<20$ & $4(1.7)$ \\
\hline $20-40$ & $133(55)$ \\
\hline $40-60$ & $91(37.6)$ \\
\hline$=>60$ & $14(5.8)$ \\
\hline \multicolumn{2}{|l|}{ Sex, n (\%) } \\
\hline Female & $127(52.5)$ \\
\hline Male & $115(47.5)$ \\
\hline \multicolumn{2}{|l|}{ Ethnicity } \\
\hline Fars & $120(49.6)$ \\
\hline Turkmen & $109(45)$ \\
\hline Sistani Persian & $13(5.4)$ \\
\hline \multicolumn{2}{|l|}{ Waves of epidemic } \\
\hline First wave & $117(48.3)$ \\
\hline Second wave & $125(51.7)$ \\
\hline \multicolumn{2}{|l|}{ Onset of olfactory dysfunction, $\mathrm{n}(\%)$} \\
\hline At the same time as general symptoms of COVID-19 & $200(82.6)$ \\
\hline Before general symptoms of COVID-19 & $27(11.2)$ \\
\hline After general symptoms of COVID-19 & $15(6.2)$ \\
\hline \multicolumn{2}{|l|}{ Severity olfactory dysfunction, $\mathrm{n}(\%)$} \\
\hline Complete olfactory dysfunction & $188(77.7)$ \\
\hline Partial olfactory dysfunction & $54(22.3)$ \\
\hline \multicolumn{2}{|l|}{ Gustatory dysfunction, n (\%) } \\
\hline Complete gustatory dysfunction & $170(70.2)$ \\
\hline Partial gustatory dysfunction & $49(20.2)$ \\
\hline
\end{tabular}




\begin{tabular}{|ll|}
\hline Variable & Frequency \\
\hline Non gustatory dysfunction & $23(9.5)$ \\
\hline Gastrointestinal dysfunction, $\mathrm{n}(\%)$ & $94(38.8)$ \\
\hline Yes & $148(61.2)$ \\
\hline No & \\
\hline Outcome of olfactory symptoms after 6 Month, $\mathrm{n}(\%)$ & $239(98.8)$ \\
\hline Recovery & $1(0.4)$ \\
\hline Partial recovery & $2(0.8)$ \\
\hline Nonrecovery & \\
\hline Outcome of Gustatory symptoms after 6 Month, $\mathrm{n}(\%)$ & $219(100)$ \\
\hline Recovery & \\
\hline
\end{tabular}

Table 1

With respect to the onset of general symptoms in COVID-19 patients (e.g. the start of fever, cough, dyspnea, fatigue, diarrhea, abdominal pain, anorexia, nausea or vomiting), the incidence of OD in 27 (11.2\%), 15 (6.2\%) and 200 (82.6\%) cases were occurred before, after and simultaneous with onset of general symptoms respectively. The mean time between OD and general symptoms was $5.03 \pm 2.32$ and $10 \pm 10.51$ days in the case of before and after onset respectively. The incidence of complete and partial forms of OD was $77.7 \%$ and $22.3 \%$, respectively. The incidences of complete and partial GD and the gastrointestinal dysfunction were $70.2 \%, 20.2 \%$ and $38.8 \%$ respectively. OD recovery status in 242 cases showed that after six months, 239 (98.8\%) patients had complete recovery, one $(0.4 \%)$ had partial recovery and two $(0.8 \%)$ had no recovery. Also, from 219 cases with GD disorder, all cases had complete recovery after six months (Table 1). The recovery times of the OD and GD was shown in Fig. 1. 80.9\% and $83.56 \%$ of patients recovered from OD and GD within the first 30 days following the onset of OD or GD, respectively (Fig. 1).

Mean and median time to recovery of OD and GD were presented in Table 2. The mean time of OD recovery in cases infected in the first peak of pandemic was significantly higher $(35.07 \pm 4.25)$ than in cases infected in the second peak $(21.65 \pm 2.05)(p=0.004)$. Also, this difference was similar for recovery time of GD $(p=0.005)$. The mean recovery time of GD was significantly higher in women $(35.55 \pm 4.33)$ than men $(23.20 \pm 2.46)(p=0.04)$. 
Table 2

Distribution of mean and median time of OD and GD recovery by patients' characteristics

\begin{tabular}{|c|c|c|c|c|}
\hline \multirow[t]{3}{*}{ Variable } & \multicolumn{2}{|c|}{ Olfactory dysfunction } & \multicolumn{2}{|c|}{ Gustatory dysfunction } \\
\hline & $\begin{array}{l}\text { Mean time of } \\
\text { OD recovery }\end{array}$ & $\begin{array}{l}\text { Median time of } \\
\text { OD recovery }\end{array}$ & $\begin{array}{l}\text { Mean time of } \\
\text { GD recovery }\end{array}$ & $\begin{array}{l}\text { Median time of } \\
\text { GD recovery }\end{array}$ \\
\hline & Mean \pm SE & Median \pm SE & Mean \pm SE & Median \pm SE \\
\hline Total & $28.05 \pm 2.33$ & $14 \pm 0.56$ & $29.52 \pm 2.55$ & $14 \pm 0.60$ \\
\hline \multicolumn{5}{|l|}{ Sex } \\
\hline Female & $32.75 \pm 3.82$ & $14 \pm 0.76$ & $35.55 \pm 4.33$ & $14 \pm 1.05$ \\
\hline \multirow[t]{2}{*}{ Male } & $22.82 \pm 2.39$ & $0.14 \pm 0.56$ & $23.20 \pm 2.46$ & $14 \pm 0.71$ \\
\hline & $0.06^{*}$ & & 0.04 & \\
\hline \multicolumn{5}{|l|}{ Age group } \\
\hline$<20$ & $8 \pm 1.41$ & $8 \pm 2$ & $8 \pm 2$ & $10 \pm 0$ \\
\hline $20-40$ & $29.13 \pm 3.29$ & $14 \pm 0.78$ & $31.18 \pm 3.70$ & $14 \pm 0.94$ \\
\hline $40-60$ & $26.58 \pm 3.62$ & $14 \pm 0.78$ & $27.09 \pm 3.78$ & $14 \pm 0.91$ \\
\hline \multirow[t]{2}{*}{$60<$} & $33.14 \pm 9.42$ & $14 \pm 3.70$ & $34.92 \pm 9.99$ & $14 \pm 8.98$ \\
\hline & 0.07 & & 0.13 & \\
\hline \multicolumn{5}{|l|}{ Ethnicity } \\
\hline Fars & $34.05 \pm 4.08$ & $14 \pm 0.95$ & $36.03 \pm 4.34$ & $15 \pm 0.98$ \\
\hline Turkmen & $22.83 \pm 2.46$ & $12 \pm 0.86$ & $23.06 \pm 2.61$ & $12 \pm 0.86$ \\
\hline \multirow[t]{2}{*}{ Sistani Persian } & $17.92 \pm 4.26$ & $14 \pm 3.59$ & $19.20 \pm 5.53$ & $7 \pm 4.34$ \\
\hline & 0.06 & & 0.04 & \\
\hline \multicolumn{5}{|l|}{ Waves } \\
\hline First wave & $35.07 \pm 4.25$ & $15 \pm 1.56$ & $36.36 \pm 4.27$ & $15 \pm 1.68$ \\
\hline \multirow[t]{2}{*}{ Second wave } & $21.65 \pm 2.05$ & $12 \pm 0.64$ & $21.66 \pm 2.22$ & $12 \pm 0.65$ \\
\hline & 0.004 & & 0.005 & \\
\hline \multicolumn{5}{|l|}{$\begin{array}{l}\text { Onset of olfactory } \\
\text { dysfunction }\end{array}$} \\
\hline $\begin{array}{l}\text { At the same time as general } \\
\text { symptoms of COVID-19 }\end{array}$ & $27.27 \pm 2.48$ & $14 \pm 0.59$ & $29.12 \pm 2.76$ & $14 \pm 0.63$ \\
\hline
\end{tabular}

*Log Rank (Mantel-Cox) test 


\begin{tabular}{|lllll|}
\hline Variable & \multicolumn{2}{l}{ Olfactory dysfunction } & \multicolumn{2}{l|}{ Gustatory dysfunction } \\
\cline { 2 - 5 } & $\begin{array}{l}\text { Mean time of } \\
\text { OD recovery } \\
\text { Mean } \pm \text { SE }\end{array}$ & $\begin{array}{c}\text { Median time of } \\
\text { OD recovery } \\
\text { Median } \pm \text { SE }\end{array}$ & $\begin{array}{l}\text { Mean time of } \\
\text { GD recovery }\end{array}$ & $\begin{array}{c}\text { Median time of } \\
\text { GD recovery }\end{array}$ \\
\hline $\begin{array}{l}\text { Before general symptoms of } \\
\text { COVID-19 }\end{array}$ & $31.25 \pm 7.59$ & $12 \pm 2.59$ & $29.92 \pm 7.88$ & $12 \pm 3.33$ \\
\hline $\begin{array}{l}\text { After general symptoms of } \\
\text { COVID-19 }\end{array}$ & $32.53 \pm 11.93$ & $14 \pm 2.65$ & $32.53 \pm 11.93$ & $14 \pm 2.65$ \\
\hline $\begin{array}{l}\text { Severity olfactory } \\
\text { dysfunction }\end{array}$ & 0.91 & 0.98 & \\
\hline $\begin{array}{l}\text { Complete olfactory } \\
\text { dysfunction }\end{array}$ & $29.76 \pm 2.69$ & $14 \pm 0.66$ & $30.80 \pm 2.92$ & $15 \pm 0.96$ \\
\hline Partial olfactory dysfunction & $22.22 \pm 4.51$ & $11 \pm 1.63$ & $25.40 \pm 5.22$ & $12 \pm 1.34$ \\
\hline & 0.07 & & 0.16 & \\
\hline Gastrointestinal dysfunction & & & & \\
\hline No & $29.93 \pm 3.23$ & $14 \pm 0.69$ & $30.91 \pm 3.55$ & $14 \pm 0.75$ \\
\hline Yes & $25.05 \pm 3.14$ & $12 \pm 0.68$ & $27.32 \pm 3.44$ & $12 \pm 1.41$ \\
\hline & 0.15 & & 0.28 & \\
\hline *Log Rank (Mantel-Cox) test & & & & \\
\hline
\end{tabular}

The final multivariable Cox-regression analysis model identified that age less than 20 years $v s$ age $>60$ year, second wave epidemic, and partial olfactory dysfunction were identified as significant predictors of OD recovery. The hazard of OD recovery among patients with age less than 20 years was 3.96 times (Adjusted Hazard Ratio (aHR): 3.96, 95\% Cl: 1.25-12.52) higher than patients age > 60-year. The hazard of OD recovery among cases that infected in the second peak of epidemic was increased by $54 \%$ (aHR: $1.54 ; 95 \% \mathrm{Cl}: 1.09-2.18)$ as compared to first peak. Furthermore, the hazard of OD recovery among individuals who had partial OD was 2.97 times (aHR: $2.97 ; 95 \% \mathrm{Cl}: 1.21-7.29)$ higher as compared to those who had complete OD (Table 3, Figs. 2, 3 and 4). Also, age less than 20 years and second peak of epidemic were significantly associated with increased aHRs for gustatory dysfunction (GD) (Table 4, Figs. 5 and 6). 
Table 3

Crude and adjusted hazard ratios for recovery of olfactory dysfunction (OD)

\begin{tabular}{|c|c|c|c|c|}
\hline Variables & $\begin{array}{l}\text { Crude HR, } \\
(95 \% \mathrm{Cl})\end{array}$ & $\begin{array}{l}\mathrm{P} \\
\text { value }\end{array}$ & $\begin{array}{l}\text { Adjusted HR, } \\
95 \% \mathrm{Cl}\end{array}$ & $\begin{array}{l}\mathrm{P} \\
\text { value }\end{array}$ \\
\hline \multicolumn{5}{|l|}{ Sex } \\
\hline Female & Ref & & Ref & \\
\hline Male & $\begin{array}{l}1.26(0.97- \\
1.63)\end{array}$ & 0.08 & $\begin{array}{l}1.26(0.96- \\
1.64)\end{array}$ & 0.09 \\
\hline \multicolumn{5}{|l|}{ Age group } \\
\hline$<20$ & $\begin{array}{l}3.50(1.13- \\
10.81)\end{array}$ & 0.02 & $\begin{array}{l}3.96(1.25- \\
12.52)\end{array}$ & 0.01 \\
\hline $20-40$ & $\begin{array}{l}1.07(0.61- \\
1.86)\end{array}$ & 0.81 & $\begin{array}{l}1.09(0.62- \\
1.92)\end{array}$ & 0.75 \\
\hline $40-60$ & $\begin{array}{l}1.07(0.60- \\
1.88)\end{array}$ & 0.81 & $\begin{array}{l}1.03(0.58- \\
1.83)\end{array}$ & 0.91 \\
\hline $60<$ & Ref & & Ref & \\
\hline \multicolumn{5}{|l|}{ Ethnicity } \\
\hline Fars & Ref & & Ref & \\
\hline Turkmen & $\begin{array}{l}1.31(1.00- \\
1.72)\end{array}$ & 0.04 & $\begin{array}{l}1.09(0.79- \\
1.51)\end{array}$ & 0.56 \\
\hline Sistani Persian & $\begin{array}{l}1.50(0.84- \\
2.69)\end{array}$ & 0.16 & $\begin{array}{l}1.22(0.63- \\
2.34)\end{array}$ & 0.54 \\
\hline \multicolumn{5}{|l|}{ Waves } \\
\hline First wave & Ref & & Ref & \\
\hline Second wave & $\begin{array}{l}1.43(1.09- \\
1.87)\end{array}$ & 0.008 & $\begin{array}{l}1.54(1.09- \\
2.18)\end{array}$ & 0.01 \\
\hline \multicolumn{5}{|l|}{ Onset of olfactory dysfunction } \\
\hline $\begin{array}{l}\text { At the same time as general symptoms of } \\
\text { COVID-19 }\end{array}$ & Ref & & Ref & \\
\hline Before general symptoms of COVID-19 & $\begin{array}{l}0.92(0.61- \\
1.38)\end{array}$ & 0.69 & $\begin{array}{l}0.94(0.60- \\
1.48)\end{array}$ & 0.80 \\
\hline After general symptoms of COVID-19 & $\begin{array}{l}0.93(0.97- \\
1.65)\end{array}$ & 0.93 & $\begin{array}{l}1.16(0.66- \\
2.04)\end{array}$ & 0.59 \\
\hline \multicolumn{5}{|l|}{ Severity olfactory dysfunction } \\
\hline Complete olfactory dysfunction & Ref & & Ref & \\
\hline
\end{tabular}




\begin{tabular}{|c|c|c|c|c|}
\hline Variables & $\begin{array}{l}\text { Crude HR, } \\
(95 \% \mathrm{Cl})\end{array}$ & $\begin{array}{l}P \\
\text { value }\end{array}$ & $\begin{array}{l}\text { Adjusted HR, } \\
95 \% \mathrm{Cl}\end{array}$ & $\begin{array}{l}\mathrm{P} \\
\text { value }\end{array}$ \\
\hline Partial olfactory dysfunction & $\begin{array}{l}1.30(0.96- \\
1.76)\end{array}$ & 0.09 & $\begin{array}{l}2.97(1.21- \\
7.29)\end{array}$ & 0.01 \\
\hline \multicolumn{5}{|l|}{ Gastrointestinal dysfunction } \\
\hline No & Ref & & Ref & \\
\hline Yes & $\begin{array}{l}1.19(0.91- \\
1.55)\end{array}$ & 0.18 & $\begin{array}{l}1.08(0.80- \\
1.44)\end{array}$ & 0.60 \\
\hline \multicolumn{5}{|l|}{ Gustatory dysfunction } \\
\hline Complete gustatory dysfunction & $\begin{array}{l}0.71(0.46- \\
1.11)\end{array}$ & 0.13 & $\begin{array}{l}0.86(0.54- \\
1.39)\end{array}$ & 0.55 \\
\hline Partial gustatory dysfunction & $\begin{array}{l}0.89(0.54- \\
1.48)\end{array}$ & 0.67 & $\begin{array}{l}0.42(0.15- \\
1.19)\end{array}$ & 0.10 \\
\hline Non gustatory dysfunction & Ref & & Ref & \\
\hline
\end{tabular}


Table 4

Crude and adjusted hazard ratios for recovery of Gustatory dysfunction (GD)

\begin{tabular}{|c|c|c|c|c|}
\hline Variables & $\begin{array}{l}\text { Crude HR, } \\
(95 \% \mathrm{Cl})\end{array}$ & $\begin{array}{l}P \\
\text { value }\end{array}$ & $\begin{array}{l}\text { Adjusted }{ }^{*} \mathrm{HR} \text {, } \\
95 \% \mathrm{Cl}\end{array}$ & $\begin{array}{l}P \\
\text { value }\end{array}$ \\
\hline \multicolumn{5}{|l|}{ Sex } \\
\hline Female & Ref & & Ref & \\
\hline Male & $\begin{array}{l}1.31(0.99- \\
1.72)\end{array}$ & 0.05 & $\begin{array}{l}1.27(0.96- \\
1.68)\end{array}$ & 0.09 \\
\hline \multicolumn{5}{|l|}{ Age group } \\
\hline$<20$ & $\begin{array}{l}3.62(1.01- \\
12.90)\end{array}$ & 0.04 & $\begin{array}{l}4.40(1.20- \\
16.09)\end{array}$ & 0.02 \\
\hline $20-40$ & $\begin{array}{l}1.06(0.60- \\
1.89)\end{array}$ & 0.82 & $\begin{array}{l}1.14(0.64- \\
2.05)\end{array}$ & 0.64 \\
\hline $40-60$ & $\begin{array}{l}1.09(0.60- \\
1.96)\end{array}$ & 0.77 & $\begin{array}{l}1.05(0.57- \\
1.90)\end{array}$ & 0.87 \\
\hline $60<$ & Ref & & Ref & \\
\hline \multicolumn{5}{|l|}{ Ethnicity } \\
\hline Fars & Ref & & Ref & \\
\hline Turkmen & $\begin{array}{l}1.36(1.03- \\
1.81)\end{array}$ & 0.03 & $\begin{array}{l}1.12(0.80- \\
1.58)\end{array}$ & 0.49 \\
\hline Sistani Persian & $\begin{array}{l}1.56(0.81- \\
3.01)\end{array}$ & 0.17 & $\begin{array}{l}1.21(0.57- \\
2.57)\end{array}$ & 0.60 \\
\hline \multicolumn{5}{|l|}{ Waves } \\
\hline First wave & Ref & & Ref & \\
\hline Second wave & $\begin{array}{l}1.45(1.10- \\
1.92)\end{array}$ & 0.009 & $\begin{array}{l}1.58(1.11- \\
2.26)\end{array}$ & 0.01 \\
\hline \multicolumn{5}{|l|}{ Onset of olfactory dysfunction } \\
\hline $\begin{array}{l}\text { At the same time as general symptoms of } \\
\text { COVID- } 19\end{array}$ & Ref & & Ref & \\
\hline Before general symptoms of COVID-19 & $\begin{array}{l}1.00(0.66- \\
1.52)\end{array}$ & 0.98 & $\begin{array}{l}1.00(0.62- \\
1.60)\end{array}$ & 0.99 \\
\hline After general symptoms of COVID-19 & $\begin{array}{l}1.03(0.61- \\
1.76)\end{array}$ & 0.88 & $\begin{array}{l}1.23(0.70- \\
2.16)\end{array}$ & 0.46 \\
\hline \multicolumn{5}{|l|}{ Severity olfactory dysfunction } \\
\hline Complete olfactory dysfunction & Ref & & Ref & \\
\hline
\end{tabular}




\begin{tabular}{|c|c|c|c|c|}
\hline Variables & $\begin{array}{l}\text { Crude HR, } \\
(95 \% \mathrm{Cl})\end{array}$ & $\begin{array}{l}P \\
\text { value }\end{array}$ & $\begin{array}{l}\text { Adjusted }{ }^{*} \mathrm{HR} \text {, } \\
95 \% \mathrm{Cl}\end{array}$ & $\begin{array}{l}P \\
\text { value }\end{array}$ \\
\hline Partial olfactory dysfunction & $\begin{array}{l}1.23(0.90- \\
1.68)\end{array}$ & 0.19 & $\begin{array}{l}1.00(0.33- \\
2.97)\end{array}$ & 0.99 \\
\hline \multicolumn{5}{|l|}{ Gastrointestinal dysfunction } \\
\hline No & Ref & & Ref & \\
\hline Yes & $\begin{array}{l}1.15(0.87- \\
1.51)\end{array}$ & 0.31 & $\begin{array}{l}1.02(0.75- \\
1.38)\end{array}$ & 0.88 \\
\hline \multicolumn{5}{|l|}{ Gustatory dysfunction } \\
\hline Complete gustatory dysfunction & Ref & & Ref & \\
\hline Partial gustatory dysfunction & $\begin{array}{l}1.27(0.92- \\
1.75)\end{array}$ & 0.13 & $\begin{array}{l}1.45(0.47- \\
4.46)\end{array}$ & 0.50 \\
\hline
\end{tabular}

\section{Discussion}

This study was designed to investigate the recovery process of OD and GD over time in patients with COVID-19. This study showed that approximately $81 \%$ of OD and $84 \%$ of GD recovered in the first 30 days of their onsets and with a mean recovery time of $35.93 \pm 27.71$ days and $37.75 \pm 29.52$ days for OD and GD respectively. In addition, age less than 20 years, incidence at the time of the second peak of pandemic and partial grade of OD are among the factors affecting the recovery from OD. Among these factors, age and incidence in the second pandemic peak were also factors affecting the recovery from GD.

In the present study $52.5 \%$ of cases were female. This higher incidence of OD in COVID-19 women patients was similar with other reports. In the study of Romero-Gameros, C.A. et al. the incidence of OD in women was $63.5 \%(21)$. In addition, the study by Chary et al. and Gorzkowski et al. reported higher incidence of OD in women than in men $(22,23)$. The study by Lechien et al. showed that $59.1 \%$ of 252 patients with COVID-19-induced OD were female (24). The results of these studies are consistent with the results of our study. However, a study by Meini et al. On 100 hospitalized patients with COVID-19 showed that men had a 2: 1 ratio of olfactory and taste disorder compared to women (25). This difference may be due to the inpatient setting of this study.

Our study showed that the mean age of patients was $39.12 \pm 11.89$ years and most patients were in the age group of 20 to 40 years. Other studies have shown almost the same findings as our study, including the study of Gorzkowski et al. that reported a mean age of $39.7 \pm 13.7$ years (23) and the study of Romero-Gameros et al. that reported a mean age of patients of $41 \pm 13$ years (21). In the study of Lechien et al., the mean age of patients was $36.9 \pm 11.4$ years (24) and in the study of Amer et al. the mean age of patients was $34.26 \pm 11.91$ years (26); but in the study of Meini et al., that conducted on hospitalized 
patients, the mean age was $65 \pm 15$ years, this difference may to be due to the difference in the studied population (25).

Based on the results of our study, in $82.6 \%$ of cases the onset of OD and general symptoms in COVID-19 patients was at the same time or simultaneous, in $11.2 \%$ of cases OD start before general symptoms, and in $6.2 \%$ of cases the onset of OD was after the general symptoms. This observation was similar to other reports. Lv et al. showed that in more than $87 \%$ of cases, the onset of OD and GD coincided with the onset of general symptoms of COVID-19 (27). Ramasamy et al. found that $15.9 \%$ of patients reported onset of OD or GD before the onset of general symptoms, $34.1 \%$ after, and $36.4 \%$ with the onset of general symptoms of COVID-19 (28). Therefore, the most common time of onset of OD coincides with the onset of general symptoms, which is consistent with the findings of our study. In addition, our study showed that in COVID-19 patients who did not develop OD at the onset of the general symptoms, the mean of time window was $5.03 \pm 2.32$ days before and $10 \pm 10.51$ days after the general symptoms. Ramasamy et al. reported that in most COVID-19 patients in their study the median duration of OD and also the complete recovery time from it was 7 days (28). In addition, the study by Chary et al., showed that OD occurred from 3 days before to 7 days after general symptoms of COVID-19 (22).

The recovery rate of OD in this study was $80.99 \%$ at the end of the first 30 days, this rate reaches $81.82 \%$ by 90 days and $98 \%$ of patients recover by 6 months. This trend was also observed for GD and in our study all cases of GD had complete recovery within 6 months of follow-up. Gorzkowski et al., showed that $95.71 \%$ of OD recovered within 26 days after the onset of OD, and $51.43 \%$ of patients achieved complete recovery (23). Meini et al. reported $82 \%$ improvement for OD during the 4-week follow-up (25). Lv et al., showed that during 4 weeks $89.7 \%$ of COVID-19 patients had GD and OD recovery (27). Paderno et al., reported $87 \%$ and $82 \%$ recovery rates for OD and GD during one month respectively (29). Hopkins et al., reported a $79 \%$ recovery rate over the course of a month (30). Amer et al., reported complete and partial OD recovery rate of 96 patients with COVID-19; this rate was $33 \%$ and $41 \%$ for complete and partial recovery respectively within 11 days, while $25 \%$ did not achieve any recovery during one month (26). In a study by Vaira et al., 7.3\% of patients still had severe disorders during the two-month follow-up (31). Cho et al. also reported an OD recovery rate of $71.8 \%$ (32). In general, the results of these studies are consistent with our findings and the comparison of the results of the above studies shows that a significant percentage of patients achieve OD and GD recovery in a short time and the difference in the percentages of recovery rates may be attributed to the assessment method of OD or GD, the duration of follow-up or genetic susceptibility to the disease.

In the present study, the mean and median of recovery time were $28.05 \pm 2.33$ and $14 \pm 0.56$ days for OD, and $29.52 \pm 2.55$ and $14 \pm 0.60$ days for GD. In study of Chary et al., the recovery time for OD and GD was 15 days (22). The OD recovery time in the study of Meini et al., was 18 days (25). In the study by Cho et al., the mean time for OD recovery was $10.3 \pm 8.3$ days (30). Gorzkowski et al., and Romero-Gameros, C.A. et al., reported 11.6 and 10 days, respectively as the mean recovery time from onset of $\operatorname{OD}(21,23)$. In the study by Cho et al., mean time for GD recovery was $9.5 \pm 6.8$ days and the complete recovery rate of GD was $83.3 \%(32)$. 
The present study did not show a significant difference for the median recovery time in patients with OD in terms of gender, age groups and ethnicity. So that the findings of the study of Chary et al. and the study of Lv et al. are in line with the results of our study $(22,27)$. However, our study showed that the median recovery time was higher in people infected with the first peak of the epidemic than in those infected in the second peak of the epidemic, which may be due to the fact that OD and GD was known in the first peak, therefore there was more knowledge about the management of OD or GD cases in the second peak and this may be the reason of the reduction of the recovery time. It may also be related to changes in the pathogenicity of SARS-Cov-2 virus. Gorzkowski et al., studied 229 patients with COVID-19 and reported higher incidence of OD in cases that were infected before March 20, 2020 and lower incidence in cases that were infected later (70.3\% vs. $53.9 \%)(23)$.

Our study showed that the probability of recovery for OD and GD over time in the under 20 years' age group is about 4 times higher than in the over 60 years' age group. The study by Paderno et al. also showed that the patients with the partial OD were more likely to recover than patients with complete OD. However, this study did not show a significant difference for recovery of OD or GD among age groups (29). Lv et al., also showed that age and gender had no effect on the improvement of OD or GD (27).

We studied the recovery of OD and GD in COVID-19 patients over a long period of time, e.g., 6 months and our result showed that $98 \%$ of patients had been recovered during this time. However, it is necessary to point out the limitations of this study. The evaluation of OD and GD in COVID-19 patients was done by means of a self-reported method and there was no objective assessment. In addition, no quantitative scale was used to classify the severity of OD or GD. The status of smoking and other co-morbidities' or diseases with potential effect on the OD or GD recovery process were not investigated. These limitations can be applied in future studies.

\section{Conclusions}

COVID-19-related OD and GD had high rate of recovery in the first month from onset of symptoms. Age of patients, severity of OD/GD and infecting in second peak of epidemic might be related to the recovery of OD or GD in patients with COVID-19. In the treatment plan of these patients it is advisable to reassure the patients about the good prognosis and recovery of OD and GD.

\section{Declarations}

\section{Acknowledgments}

We thank the staff of the 5-Azar Hospital of Golestan University of Medical Sciences for facilitating access to the relevant medical records.

\section{Authors' contributions}


MHT and SMH performed the study. AR and MM analyzed the data and wrote the manuscript. AT and MHT provided clinical data. MAV helped the statistical analysis. AR, MM, MHT and SMH helped edit the paper. MHT and SMH supervised the study and applied for grants. All authors read and approved the final manuscript.

\section{Funding}

None.

\section{Availability of data and materials}

The datasets used and/or analyzed during the current study are available from the corresponding author on reasonable request.

\section{Ethical approval and consent to participate}

The study was approved by the Ethics Committee of Golestan University of Medical Sciences (No. IR.GOUMS.REC.1399.031). Patients received clear oral information. Their oral consent was obtained through telephone interviews.

\section{Consent for publication}

Not applicable.

\section{Competing interests}

The authors declare no conflict of interest.

\section{References}

1. Mao L, Jin H, Wang M, Hu Y, Chen S, He Q, et al. Neurologic manifestations of hospitalized patients with coronavirus disease 2019 in Wuhan, China. JAMA neurology. 2020;77(6):683-90.

2. Chan JF-W, Yuan S, Kok K-H, To KK-W, Chu H, Yang J, et al. A familial cluster of pneumonia associated with the 2019 novel coronavirus indicating person-to-person transmission: a study of a family cluster. The Lancet. 2020;395(10223):514-23.

3. Bartenfeld M, Griese S, Uyeki T, Gerber SI, Peacock G. Middle East respiratory syndrome coronavirus and children: what pediatric health care professionals need to know. Clin Pediatr. 2017;56(2):187-9.

4. Shen K, Yang Y, Wang T, Zhao D, Jiang Y, Jin R, et al. Diagnosis, treatment, and prevention of 2019 novel coronavirus infection in children: experts' consensus statement. World journal of pediatrics. 2020:1-9.

5. Memish ZA, Al-Tawfiq JA, Assiri A, AlRabiah FA, Al Hajjar S, Albarrak A, et al. Middle East respiratory syndrome coronavirus disease in children. Pediatr Infect Dis J. 2014;33(9):904-6. 
6. Feng K, Yun Y, Wang X, Yang G, Zheng Y, Lin C, et al. Analysis of CT features of 15 children with 2019 novel coronavirus infection. Zhonghua er ke za zhi = Chinese. journal of pediatrics. 2020;58:E007-E.

7. Pan X, Chen D, Xia Y, Wu X, Li T, Ou X, et al. Asymptomatic cases in a family cluster with SARS-CoV-2 infection. Lancet Infect Dis. 2020;20(4):410-1.

8. Vaira LA, Salzano G, Deiana G, De Riu G. Anosmia and Ageusia: Common Findings in COVID-19 Patients. Laryngoscope. 2020 Jul;130(7):1787. DOI:10.1002/lary.28692.).

9. Guo Y-R, Cao Q-D, Hong Z-S, Tan Y-Y, Chen S-D, Jin H-J, et al. The origin, transmission and clinical therapies on coronavirus disease 2019 (COVID-19) outbreak-an update on the status. Military Medical Research. 2020;7(1):1-10.

10. Guan W-j, Ni Z-y, Hu Y, Liang W-h, Ou C-q, He J-x, et al. Clinical characteristics of coronavirus disease 2019 in China. New England journal of medicine. 2020;382(18):1708-20.

11. Huang C, Wang Y, Li X, Ren L, Zhao J, Hu Y, et al. Clinical features of patients infected with 2019 novel coronavirus in Wuhan, China. The lancet. 2020;395(10223):497-506.

12. Vent J, Wang D-W, Damm M. Effects of traditional Chinese acupuncture in post-viral olfactory dysfunction. Otolaryngology-Head Neck Surgery. 2010;142(4):505-9.

13. Michael W. Anosmia treated with acupuncture. Acupuncture in medicine. 2003;21(4):153-4.

14. Taziki Balajelini MH, Vakili MA, Saeidi M, et al. Using Anti-SARS-CoV-2 IgG and IgM Antibodies to Detect Outpatient Cases with Olfactory and Taste Disorders Suspected as Mild Form of COVID-19: a Retrospective Survey. SN Compr Clin Med. 2020. https://doi.org/10.1007/s42399-020-00623-3.

15. Temmel AF, Quint C, Schickinger-Fischer B, Klimek L, Stoller E, Hummel T. Characteristics of olfactory disorders in relation to major causes of olfactory loss. Archives of Otolaryngology-Head Neck Surgery. 2002;128(6):635-41.

16. Palheta Neto FX, Targino MN, Peixoto VS, Alcântara FB, Jesus CCd. Araújo DCd, et al. Anormalidades sensoriais: olfato e paladar. Arquivos Internacionais de Otorrinolaringologia. 2011;15(3):350-8.

17. Dai Q, Pang Z, Yu H. Recovery of olfactory function in postviral olfactory dysfunction patients after acupuncture treatment. Evidence-Based Complementary and Alternative Medicine. 2016;2016.

18. Hendriks A. Olfactory dysfunction. Rhinology. 1988;26(4):229-51.

19. Reden J, Mueller A, Mueller C, Konstantinidis I, Frasnelli J, Landis BN, et al. Recovery of olfactory function following closed head injury or infections of the upper respiratory tract. Archives of Otolaryngology-Head Neck Surgery. 2006;132(3):265-9.

20. Offringa DP, Tyson-Medlock V, Ye Z, Levandowski RA. A comprehensive systematic approach to identification of influenza A virus genotype using RT-PCR and RFLP. J Virol Methods. 2000;88(1):1524.

21. Romero-Gameros CA, Waizel-Haiat S, Mendoza-Zubieta V, Anaya-Dyck A, López-Moreno MA, ${ }^{*}$ ColinMartinez T, et al. Evaluation of predictive value of olfactory dysfunction, as a screening tool for COVID-19. Laryngoscope Investigative Otolaryngology. 2020. 
22. Chary E, Carsuzaa F, Trijolet J-P, Capitaine A-L, Roncato-Saberan M, Fouet K, et al. Prevalence and Recovery From Olfactory and Gustatory Dysfunctions in COVID-19 Infection: A Prospective Multicenter Study. American Journal of Rhinology \& Allergy. 2020:1945892420930954.

23. Gorzkowski V, Bevilacqua S, Charmillon A, Jankowski R, Gallet P, Rumeau C, et al. Evolution of olfactory disorders in COVID-19 patients. Laryngoscope. 2020;130(11):2667-73.

24. Lechien JR, Chiesa-Estomba CM, De Siati DR, Horoi M, Le Bon SD, Rodriguez A, et al. Olfactory and gustatory dysfunctions as a clinical presentation of mild-to-moderate forms of the coronavirus disease (COVID-19): a multicenter European study. European Archives of Oto-Rhino-Laryngology. 2020:1-11.

25. Meini S, Suardi LR, Busoni M, Roberts AT, Fortini A. Olfactory and gustatory dysfunctions in 100 patients hospitalized for COVID-19: sex differences and recovery time in real-life. European Archives of Oto-Rhino-Laryngology. 2020:1.

26. Amer MA, Elsherif HS, Abdel-Hamid AS, Elzayat S. Early recovery patterns of olfactory disorders in COVID-19 patients; a clinical cohort study. Am J Otolaryngol. 2020;41(6):102725.

27. Lv H, Zhang W, Zhu Z, Xiong Q, Xiang R, Wang Y, et al. Prevalence and recovery time of olfactory and gustatory dysfunction in hospitalized patients with COVID-19 in Wuhan, China. International Journal of Infectious Diseases. 2020;100:507-12.

28. Ramasamy K, Saniasiaya J, Abdul Gani N Olfactory and Gustatory Dysfunctions as a Clinical Manifestation of Coronavirus Disease 2019 in a Malaysian Tertiary Center. Annals of Otology, Rhinology \& Laryngology. 2020:0003489420963165.

29. Paderno A, Mattavelli D, Rampinelli V, Grammatica A, Raffetti E, Tomasoni M, et al. Olfactory and gustatory outcomes in COVID-19: A prospective evaluation in nonhospitalized subjects. Otolaryngology-Head and Neck Surgery. 2020.

30. Hopkins C, Surda P, Whitehead E, Kumar BN. Early recovery following new onset anosmia during the COVID-19 pandemic-an observational cohort study. Journal of Otolaryngology-Head Neck Surgery. 2020;49:1-6.

31. Vaira LA, Hopkins C, Petrocelli M, Lechien J, Chiesa-Estomba C, Salzano G, et al. Smell and taste recovery in coronavirus disease 2019 patients: a 60-day objective and prospective study. The Journal of Laryngology Otology. 2020;134(8):703-9.

32. Cho RH, To ZW, Yeung ZW, Tso EY, Fung KS, Chau SK, et al. COVID-19 Viral Load in the Severity of and Recovery from Olfactory and Gustatory Dysfunction. Laryngoscope. 2020;130(11):2680-5.

\section{Figures}


100.00

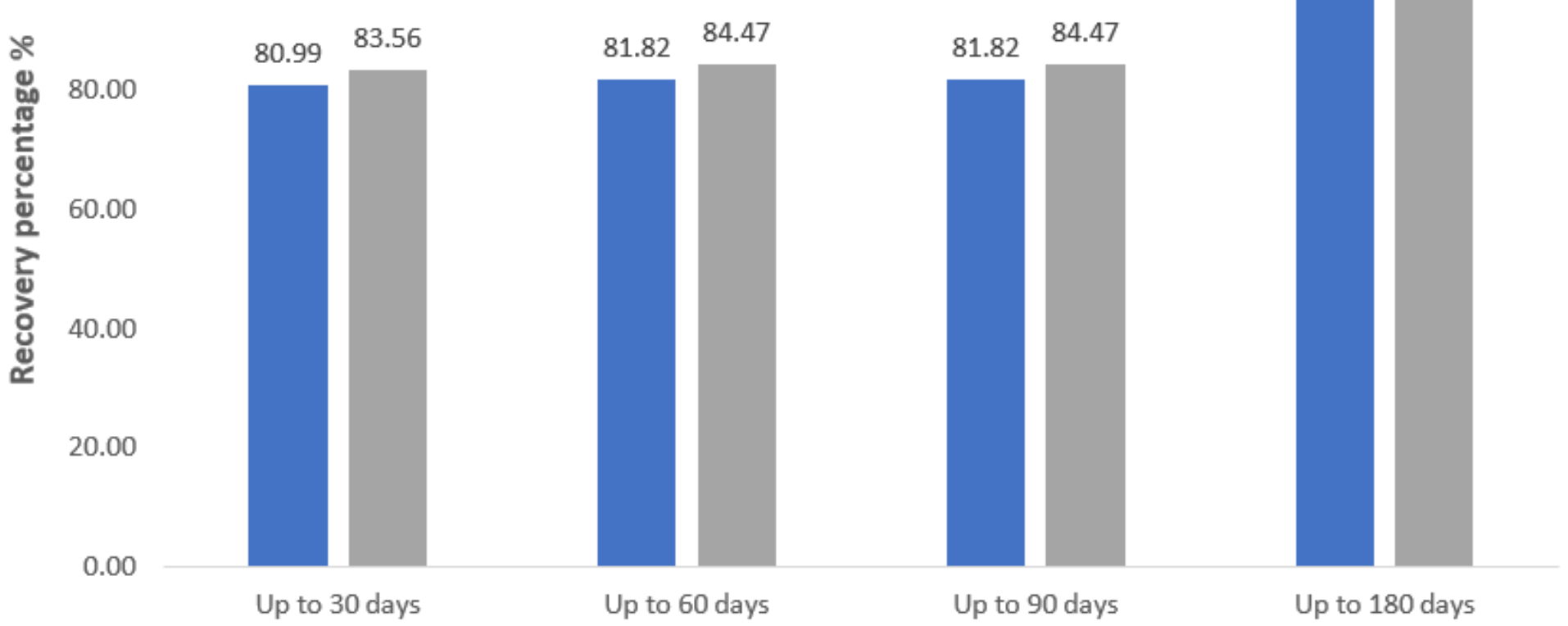

Follow up time group

- Complete recovery OD $\quad$ Complete recovery GD

Figure 1

Pattern of recovery time for patients with olfactory and gustatory dysfunction

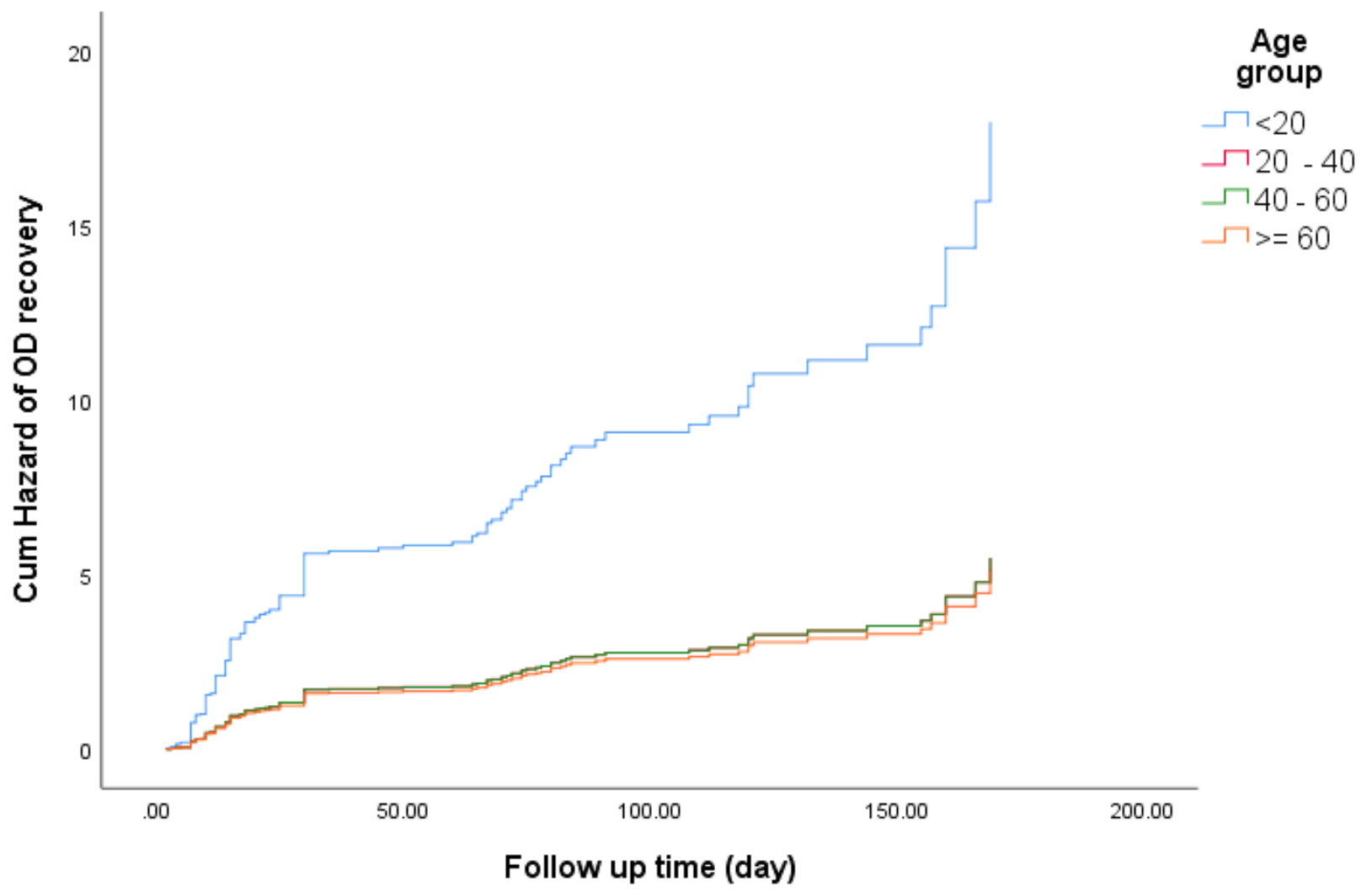


Figure 2

The cumulative hazard of recovery of OD over age group from February to July 2020

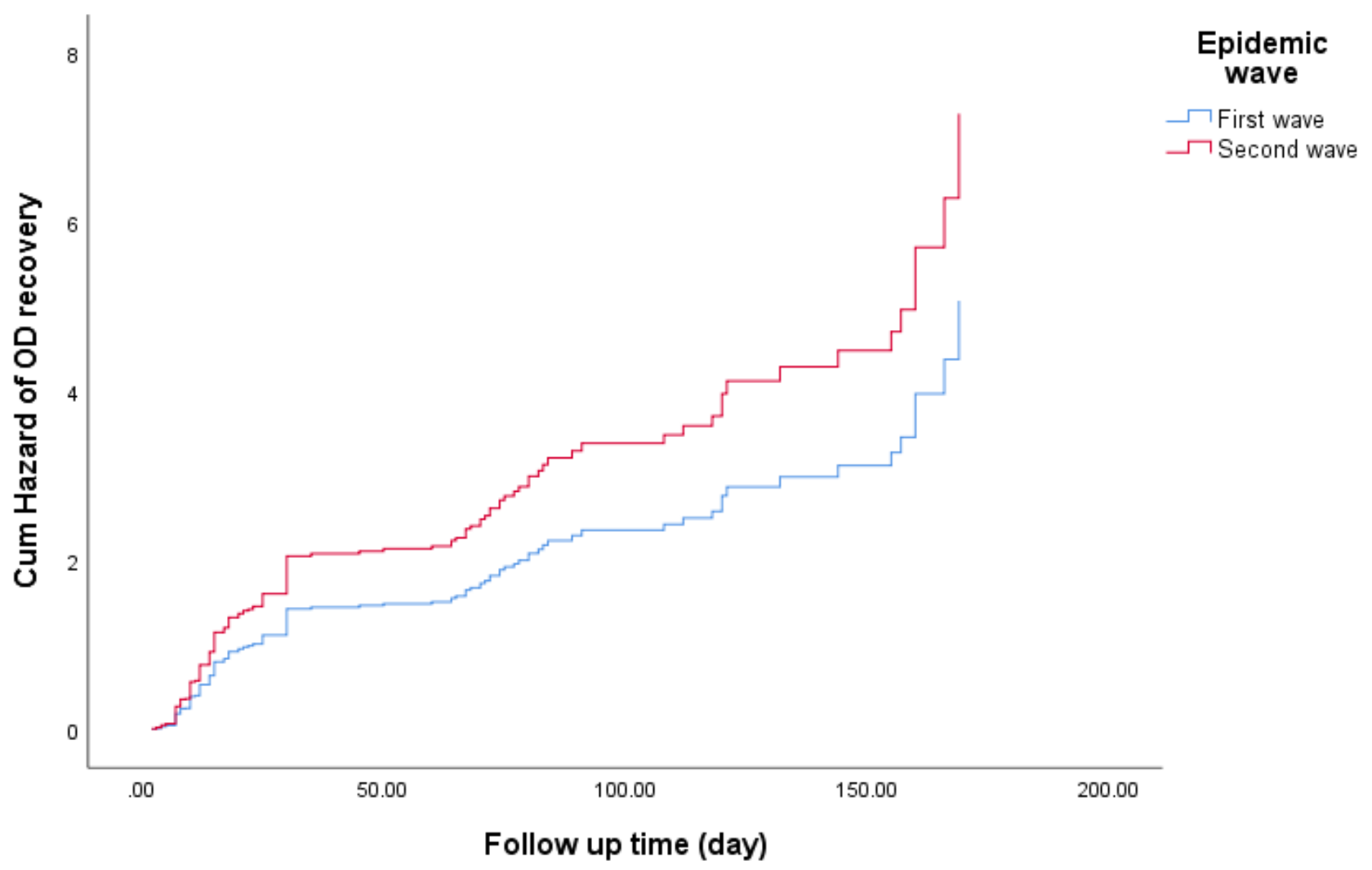

\section{Figure 3}

The cumulative hazard of recovery of OD over epidemic wave from February to July 2020 


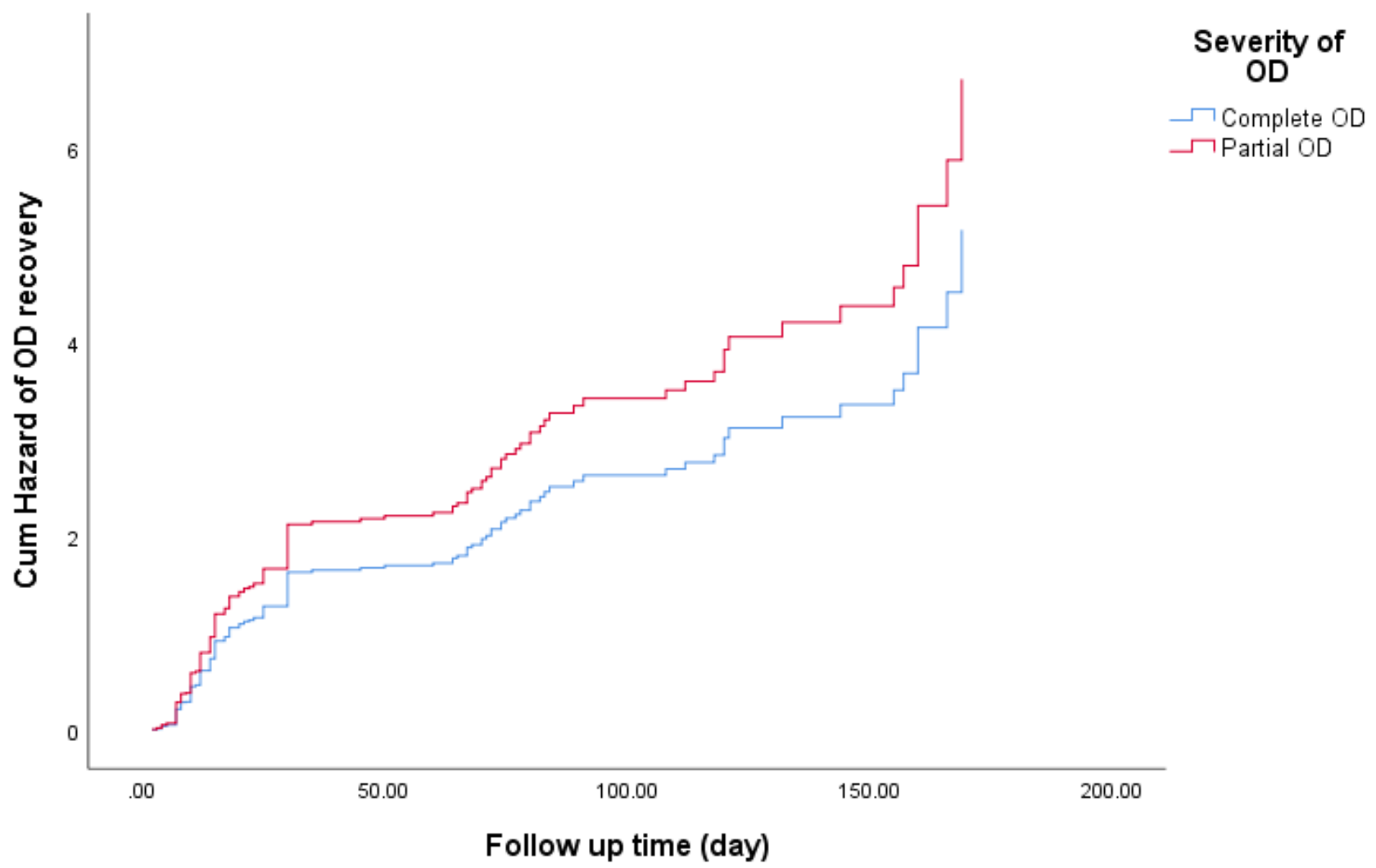

Figure 4

The cumulative hazard of recovery of OD over severity of OD from February to July 2020 


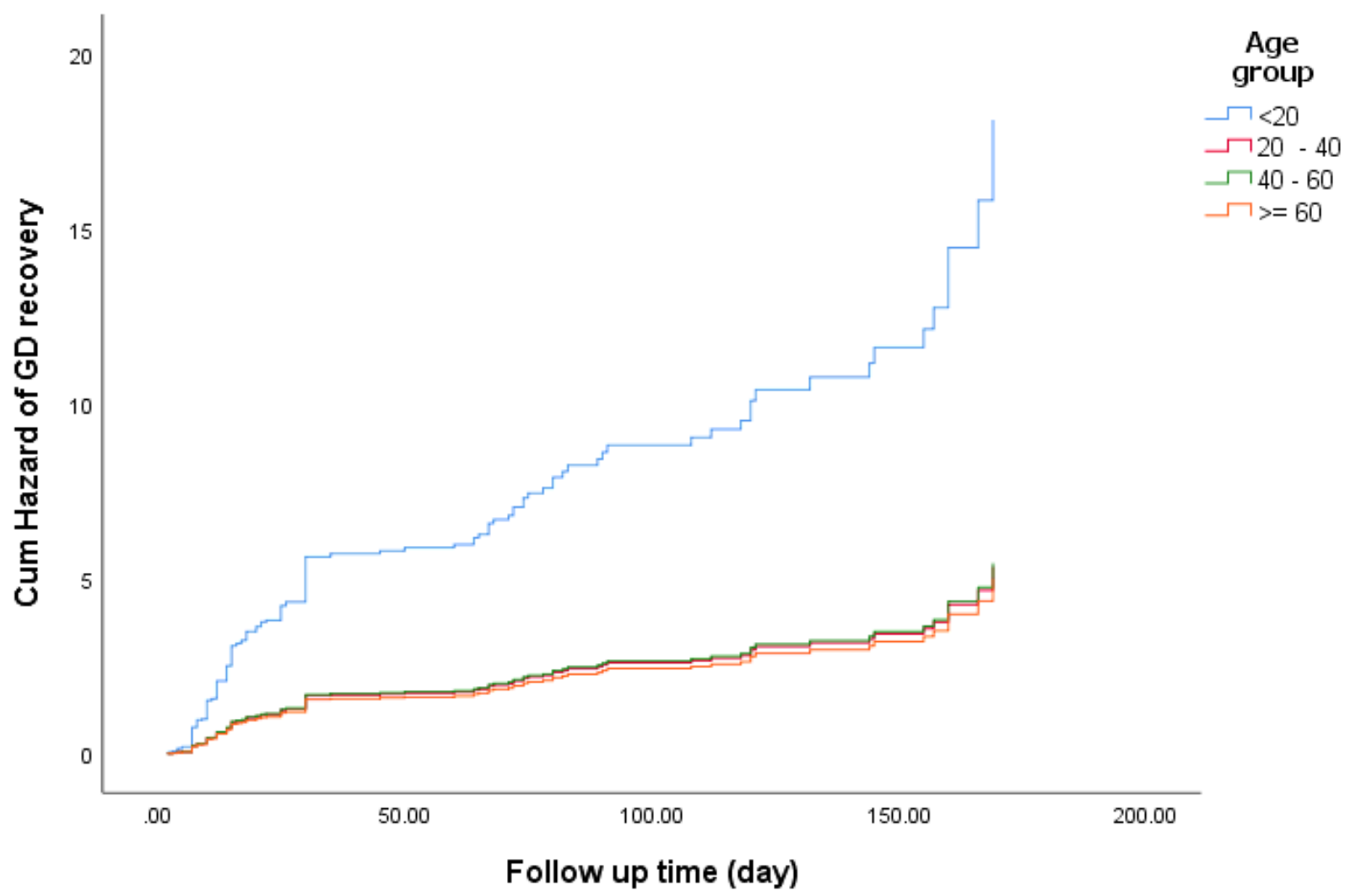

Figure 5

The cumulative hazard of recovery of GD over age group from February to July 2020 


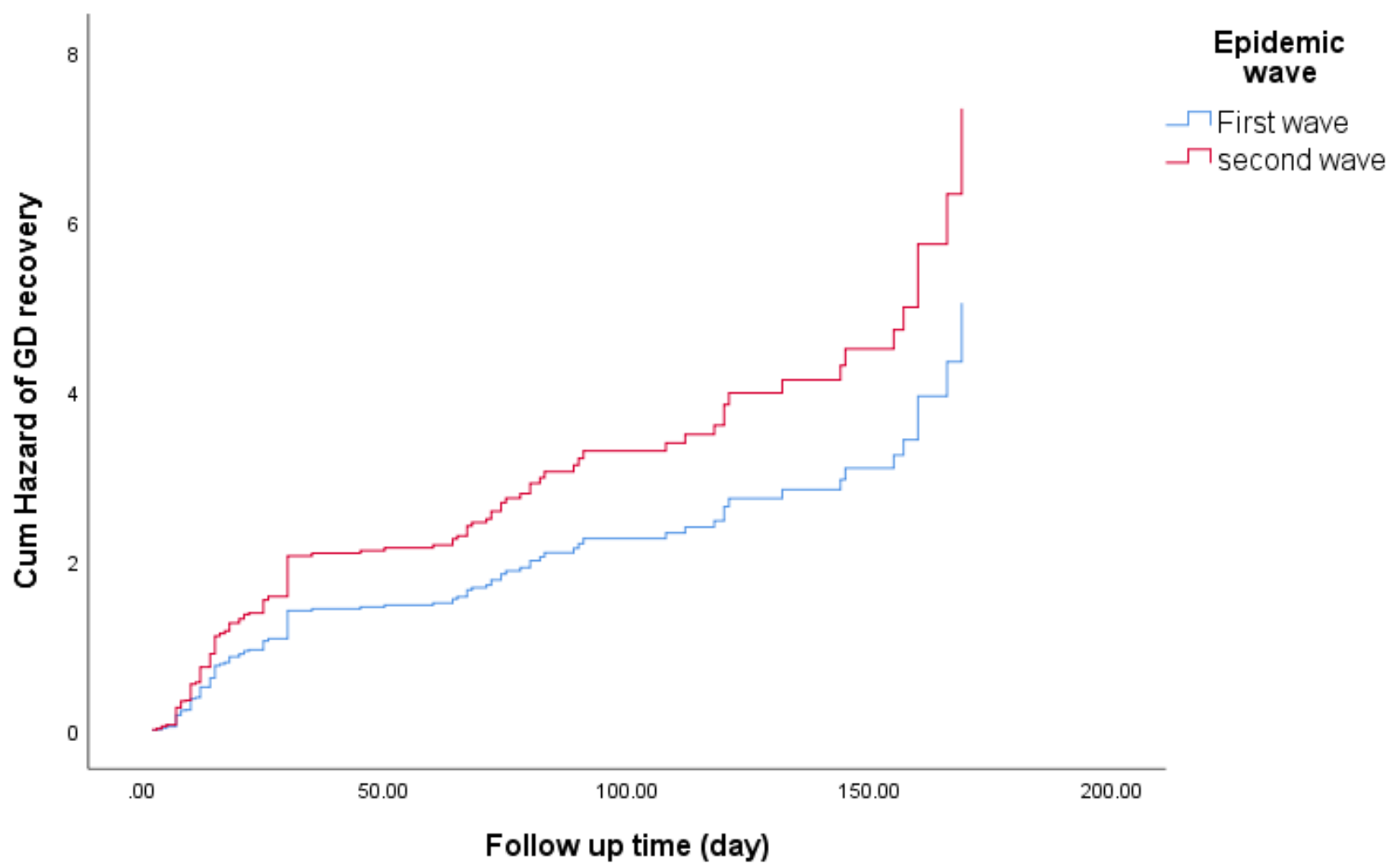

Figure 6

The cumulative hazard of recovery of GD over epidemic wave from February to July 2020

\section{Supplementary Files}

This is a list of supplementary files associated with this preprint. Click to download.

- Graphicalabstract.docx 